\title{
Chapter 19 \\ Recovery of Starch from Sago Pith Waste and Waste Water Treatment
}

\author{
Budi Santoso
}

\begin{abstract}
The objective of this study was to investigate sago starch recovery from sago pith waste (SPW) using wet milling and its physical properties. For comparative purposes, the same parameters were evaluated for untreated sago starch. As a result of the super mass colloider mill (SMCM), a 21\% dry basis of sago starch can be recovered from SPW. Scanning electron microscopy showed that the granule morphology was not changed. X-ray diffraction showed that relative crystallinity and diffractogram patterns between SMCM sago starch and untreated sago starch were similar. Particle size distribution analysis demonstrated that untreated and SMCM sago starch were relatively narrow and uniform size distribution and the particle size distribution index were not different. The results indicate that wet milling of SPW using a SMCM can increase sago starch yield and the physical properties of SMCM sago starch were similar to untreated sago starch.
\end{abstract}

\subsection{Introduction}

At present, food security is a serious issue in the world because the population rate continues to increase. According to the US Census Bureau (2014), the world population was around 6.1 billion in 2000 and increased by about $13 \%$ (to 6.9 billion) in 2010. It is projected that the population of the world, with an average growth rate of about $0.8 \%$, will increase in billions to 8.3 by 2030, 8.9 by 2040, and 9.4 by 2050 . This indicates that by 2050 the world needs to produce $50 \%$ more food than it does now to feed around 9 billion people.

In the world, there are various plant sources of starch, such as rice, wheat, corn, potato, sweet potato, cassava, barley, and sago. Among carbohydrate polymers, starch is currently enjoying increased attention owing to its usefulness in different food products. Starch contributes greatly to the textural properties of many foods and is widely used in food and industrial applications as a thickener, colloidal stabilizer, gelling agent, bulking agent, and water retention agent (Singh et al. 2007).

\footnotetext{
B. Santoso $(\square)$

Faculty of Agricultural Technology, Papua University, Manokwari, West Papua, Indonesia

e-mail: budsandida@yahoo.com
} 
Industries use starch to give products certain properties, such as consistency and mouthfeel in food products or sizing of textiles. While some products require very specific kinds of starch, for most starch uses, there is a high degree of substitutability between one starch and another (Fuglie 2004). The utilization of starch sources depends on the functional properties of starches including thickening behavior and the ability to form a gel or paste. The textural properties of gelatinized and retrograded starches are important for their potential use in food systems and depend on the molecular component and structure of the starch (Adawiyah et al. 2013).

Recently, attention to sago starch as a new food and a food security crop has increased, especially due to the anticipated growth in human population and potential future environmental disasters (Yamamoto 2011). Sago starch has not only foodstuff potential but also can be used as a bio-resource, such as ethanol (Ishizaki 1998). Compared to other starches, sago starch has low cost of production and high yield. Also, sago produces a higher amount of starch, around 15-20 mt of air-dried starch per hectare (Flach 1997). The sago yield could be about 3-4 times higher than those of rice, corn, or wheat and about 17 times higher than that of cassava (Ishizaki 1998; Singhal et al. 2008).

The sago palm is an underutilized potential food source which grows well in the tropical rainforest. Sago palm is adapted to the tropical areas with an average temperature of $25{ }^{\circ} \mathrm{C}$ and approximate relative humidity of $70 \%$; an extremely hardy plant, it thrives in swampy, acidic peat and saline soils where other crops cannot survive (Flach and Schuilling 1989; Flach 1997). The three leading countries in terms of approximate areas of sago palms are Indonesia with 1,284,000, Papua New Guinea 1,020,000, and Malaysia 45,000 ha (Flach 1997). Agronomically, sago palm is a potentially important indigenous crop of Southeast Asia and Oceania which has remained relatively underexploited (Flach 1983). It is estimated that about 60 million $\mathrm{mt}$ of starch, extracted from sago palms, are produced per annum in Southeast Asia alone (Wang et al. 1996).

\subsection{Problems of Sago Starch Extraction}

Sago starch accumulates in the trunk of the sago palm until the flowering stage, with maximum starch content occurring just before the onset of palm flowers; the palm slowly dies thereafter. The plant reaches commercial maturity at 9-12 years of age. At the mature stage, it possesses a large trunk and may reach a height of 6-25 $\mathrm{m}$ and a diameter of $40 \mathrm{~cm}$ (Flach 1997). Sago starch can be extracted by maceration of the pith of a sago trunk. Extracting starch from the sago trunk, according to Nishimura et al. (2010), involves tree felling, cutting the trunk into log sections, log splitting, pith crushing, starch filtering, starch extraction, drying, and packaging. However, the method of extraction in different locations is quite diverse depending on starch use, local resource use, and economic factors among different ethnic groups.

The sago starch extraction process can be divided into two methods: traditional and modern. The principles of sago extraction for both methods are similar; the 
differences are only in the scale of operation (Karim et al. 2008) and the processing tools that are used (Greenhill 2006). The traditional method is further divided into two levels, the domestic level and the small-scale processing plant level. The smallscale level of sago starch extraction uses electrical power on some processors. Santoso et al. (2015) found that the actual starch content in the pith is about 65\% with fiber making up the remaining $35 \%$. The mechanical process currently employed to extract sago starch is inefficient and often fails to dislodge residual starch embedded in the fibrous portion of the trunks (Karim et al. 2008). Several studies have found that sago starch can be extracted using commercial methods, only up to 55-70\% (dry weight basis) of the true sago starch content. The remaining starch is still trapped within the parenchyma cells or fibers in the sago pith waste (Mohd et al. 2001; Awg-Adeni et al. 2013; Lai et al. 2013).

Sago pith waste still contains a lot of starch. According to Abd-Aziz (2002), the composition of sago pith waste on a dry weight basis contains $65.7 \%$ starch, $14.8 \%$ crude fiber, $1 \%$ crude protein, $4.1 \%$ ash, and $59.1 \%$ moisture. Linggang et al. (2012) reported that sago pith waste contains $58 \%$ starch, $23 \%$ cellulose, $9.2 \%$ hemicellulose, and 4\% lignin on a dry basis. Awg-Adeni et al. (2013) state that on a dry basis, the proportions of sago pith waste consist of 30-45\% starch, 5-7\% ash, $1 \%$ protein, and $4.6-4.7 \%$ fiber. Several studies have been done on utilizing sago pith waste as a substrate for the production of enzymes and adsorbents (Singhal et al. 2008), glucose syrup (Asben et al. 2011; Linggang et al. 2012), fructose syrup (Mishima et al. 2011), bioethanol (Awg-Adeni et al. 2011; Peristiwati et al. 2011), and biobutanol (Linggang et al. 2011; Awg-Adeni et al. 2013).

\subsection{Recovery of Starch from Sago Pith Waste}

According to Cecil (1992) and Mohd et al. (2001), the starch in sago pith waste is trapped within the parenchyma cells or fibers. To liberate the starch, it is necessary to break down the sago pith waste. There are two ways to recover starch from sago pith waste, enzymatically and physically. Recovering starch from sago pith waste using enzymes was introduced by Mohd et al. (2001). The residual native starch was extracted from sago pith residue using two types of commercial cell wall-degrading enzymes, Pectinex Ultra SP-L and Ultrazyme 100G. The results showed that the type of enzyme produced different effects to release starch from pith waste. The highest starch yield was achieved using Pectinex; after $1 \mathrm{~h}$ reaction time it yielded $42.3 \%$, dry weight basis, and then declined. By comparison, the Ultrazyme had a high yield at $2 \mathrm{~h}$ reaction time of $28.4 \%$. The physical appearance of the starch granules showed that more larger granules were extracted using Pectinex, while the distributional pattern of starch granules was more uniform with the Ultrazyme treatment during the 30 min-incubation period (Mohd et al. 2001).

Physically, recovery of starch from pith waste with further grating (secondary grating), by using a hammer mill, gives a small increase in yield of only around $3-5 \%$ and then makes separation of the sago starch from fibers difficult (Cecil 
1992). This method is not efficient for small and medium sago factories. Another way to recover starch from sago pith waste is through the use of a super mass colloider mill (Santoso et al. 2015). A micro powder mill is a dry milling method commonly used for milling cereals and grains, but also can be used to physically separate the starch from sago pith waste. This method is practical because industrial operation of a micro powder mill is easy. The yields of sago starch can be increased to around $17 \%$ (dry weight basis) when the milling process is performed at a medium narrow level of disc clearance; this was easier as compared with a narrow level of disc clearance. Based on scanning electron microscopy (SEM) micrographs (Fig. 19.1), the granule surfaces in native sago starch are smooth and oval, without any pores and fissures, and with diameters in the range 20-60 $\mu \mathrm{m}$ (Cecil 1992; Ahmad et al. 1999). The granular surface of starch from sago pith waste has slightly rough granules. When the starch is observed under polarized light (Fig. 19.2), the
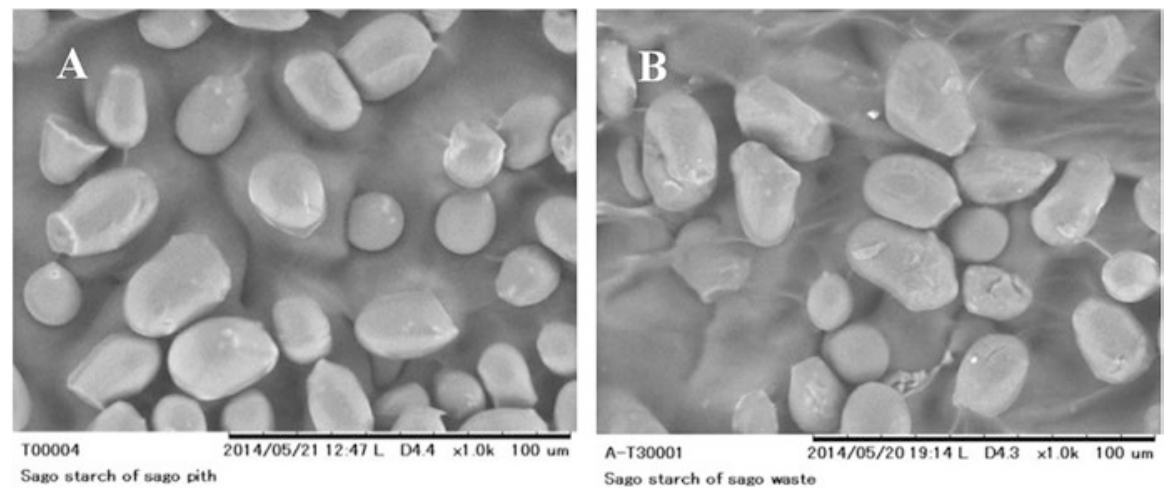

Fig. 19.1 Scanning electron microscopy images of sago starch, (a) native sago starch and (b) micro-powder-milled sago starch (magnification is 1000x)
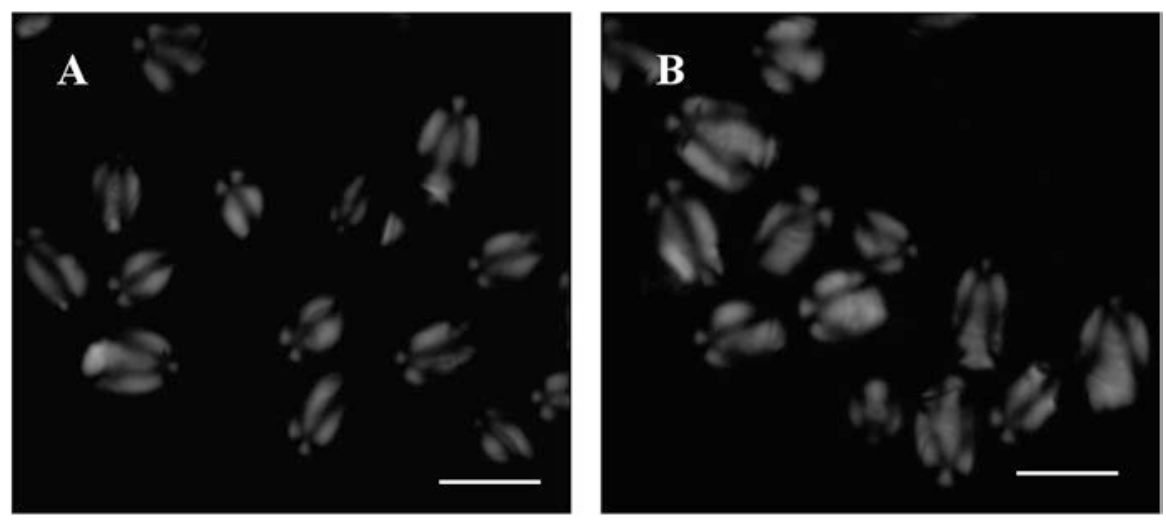

Fig. 19.2 Microscopy photographs with polarized light for (a) native sago starch and (b) micropowder-milled sago starch (magnification is $40 \times$ and bar indicates $50 \mu \mathrm{m}$ ) 
birefringence of micro-powder-milled sago starch is unchanged compared to native sago starch, with strong patterns at the granule centers; the typical Maltese crosses are uniform, with two crossed lines and a dark line at the center. According to Stahl et al. (2007), the birefringent and Maltese cross pattern can be observed on all of the native starch granules under polarized light.

The XRD pattern and the relative crystallinities of native sago starch and micropowder-milled sago starch are presented in Fig. 19.3 and Table 19.1. Native sago starch has a C-type diffraction pattern. The $\mathrm{C}$ type is a mixture of both $\mathrm{A}$ and $\mathrm{B}$ type. A-type pattern is associated mainly with cereal starches and has main peaks at $\sim 15$, 17, 18, and $23^{\circ}$ (Huijbrechts et al. 2008; O'Brien and Wang 2008; Hu et al. 2014). B-type pattern is usually obtained from tuber starches and shows main peaks at 5.6, 15, 17, 22, and 24 (O'Brien and Wang 2008; Alvani et al. 2011). The C type formed when both A- and B-polymorphic arrangement coexist and are characterized by diffraction peaks at $2 \theta$ values of around $5^{\circ}$ and strong peaks at around $\sim 15$, 17,18 , and $23^{\circ}$ (Karim et al. 2008; Wang et al. 2008). Although the relative crystallinities of micro-powder-milled sago starch are slightly decreased (Table 19.1), the XRD pattern (Fig. 19.3) shows no difference between these two starches.

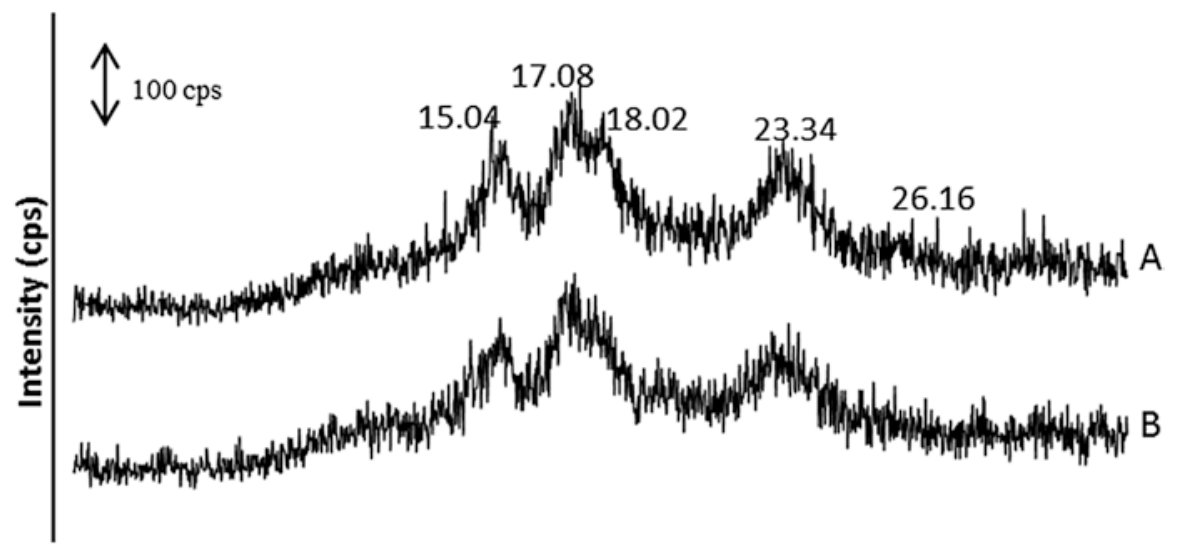

Fig. 19.3 X-ray diffraction patterns of (a) native sago starch and (b) micro-powder-milled sago starch

Table 19.1 Relative crystallinities and gelatinization properties of sago $\mathrm{starch}^{\mathrm{a}}$

\begin{tabular}{l|l|l|l|l|c|l}
\hline & \multirow{6}{|c|}{ Gelatinization properties } \\
\cline { 3 - 7 } Treatment & $\mathrm{RC}(\%)$ & $T_{\mathrm{o}}\left({ }^{\circ} \mathrm{C}\right)$ & $T_{\mathrm{p}}\left({ }^{\circ} \mathrm{C}\right)$ & $T_{\mathrm{c}}\left({ }^{\circ} \mathrm{C}\right)$ & Range $\left(T_{\mathrm{c}}-T_{\mathrm{o}}\right)\left({ }^{\circ} \mathrm{C}\right)$ & $\Delta H(\mathrm{~J} / \mathrm{g})$ \\
\hline A & $30.5 \pm 1.8$ & $56.3 \pm 0.3$ & $66.9 \pm 0.0$ & $75.9 \pm 0.1$ & $19.6 \pm 0.1$ & $15.4 \pm 0.5$ \\
\hline B & $22.1 \pm 1.1$ & $56.3 \pm 0.3$ & $66.3 \pm 0.1$ & $74.6 \pm 0.0$ & $18.3 \pm 0.3$ & $11.9 \pm 0.6$ \\
\hline
\end{tabular}

$R C$ relative crystallinity, $T_{\mathrm{o}}$ onset temperature, $T_{\mathrm{p}}$ peak temperature, $T_{\mathrm{c}}$ conclusion temperature, $\Delta H$ enthalpy

A native sago starch, B micro-powder-milled sago starch

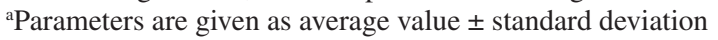



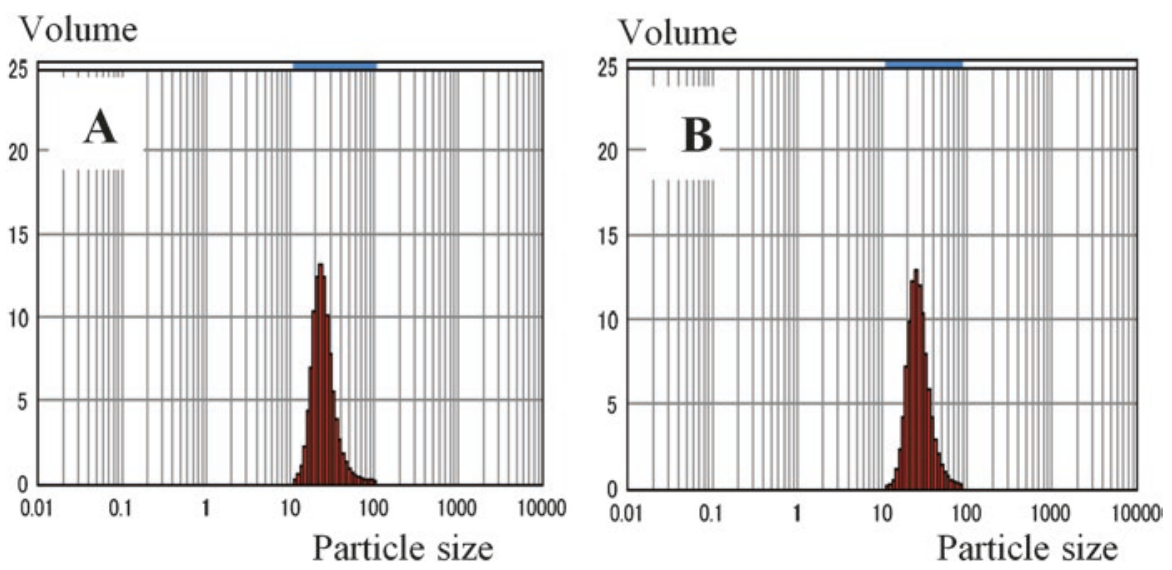

Fig. 19.4 Particle size distribution of (a) native sago starch and (b) micro-powder-milled sago starch

Table 19.2 Size distributions of sago $\operatorname{starch}^{\mathrm{a}}$

\begin{tabular}{l|l|l|l|l}
\hline \multirow{2}{*}{ Treatment } & \multicolumn{4}{l}{ Particle size } \\
\cline { 2 - 5 } & $D_{(v, 0.1)}(\mu \mathrm{m})$ & $D_{(v, 0.5)}(\mu \mathrm{m})$ & $D_{(v, 0.9)}(\mu \mathrm{m})$ & Span $^{\mathrm{b}}$ \\
\hline A & $17.3 \pm 0.1$ & $23.8 \pm 0.1$ & $36.4 \pm 0.2$ & $0.8 \pm 0.0$ \\
\hline B & $18.9 \pm 0.0$ & $26.1 \pm 0.1$ & $40.1 \pm 0.6$ & $0.8 \pm 0.0$
\end{tabular}

A native sago starch, B micro-powder-milled sago starch

aParameters are given as average value \pm standard deviation

${ }^{\mathrm{b}}$ Span: size dispersion index

Table 19.1 shows the gelatinization temperatures for native and micro-powdermilled sago starch. The onset temperature $\left(T_{\mathrm{o}}\right)$, peak temperature $\left(T_{\mathrm{p}}\right)$, and conclusion temperature $\left(T_{\mathrm{c}}\right)$ did not differ much for all treatments. The enthalpy of gelatinization $(\Delta H)$ slightly decreased from $15.4 \mathrm{~J} / \mathrm{g}$ for native sago starch to $11.9 \mathrm{~J} / \mathrm{g}$ for micro-powder-milled sago starch. This suggests that the physical force of micro powder milling is not disrupting the crystalline structure.

Graphic representation of particle size distribution of the native and micropowder-milled sago starch is shown in Fig. 19.4, and the mean diameters and spans are summarized in Table 19.2. The average sizes of the granules of micro-powdermilled sago starch were slightly higher than that of native sago starch; the span reflects the width of the starch granules. The span of native sago starch did not differ from micro-powder-milled sago starch. 


\subsection{Waste Water Treatment}

The type of waste from a sago starch factory is not only pith waste but also effluent waste. The effluent has the potential to cause water pollution in the surrounding environment due to containing a large amount of organic material. Furthermore, Singhal et al. (2008) stated that a high biomass concentration of $2.5 \mathrm{~g} / \mathrm{L}$ with a pigment content of about $1.1 \mathrm{mg}$ carotenoid per $\mathrm{g}$ cell mass was achieved after $96 \mathrm{~h}$ of growth in anaerobic-light culture system together with a $77 \%$ reduction in the COD (chemical oxygen demand) of the sago effluent.

Meanwhile, according to Mishima (2015), the sago factory effluent contains finely milled fibers, inextricable starch, and polyphenols and is discolored and prone to putrefaction. Existing treatment methods such as the use of sedimentation ponds have had detrimental effects on neighboring areas, such as a foul odor. More positive waste water treatment operations are hoped for. On the flip side, waste water contains abundant carbohydrates. The application of this material as a biomass resource might lead to new products instead of waste treatment.

\subsection{Conclusion}

Loss of starch in the sago starch extraction process is very high because the extraction methods cannot recover all of starch embedded in the fibrous portion of the trunks. This is a problem in sago starch production process for producers of sago palms. The average of sago starch recovery from sago pith waste using enzymes was $35.35 \%$ on a dry weight basis (28.4-42.3\%). Whereas sago starch yield can be increased to around $17 \%$ (dry weight basis) when sago pith waste is passed through a micro powder mill. According to Mohd et al. (2001), in Malaysia the total annual of starch disposed of as sago pith waste is estimated at 20,000 $\mathrm{mt}$. Therefore, both enzymes and a micro powder mill recovery can increase sago starch production by around 3400-7070 mt annually. This yield is very valuable and calls attention to the sago palm as a new food and a food security crop in the world. The sago factory effluent contains a large amount of organic material, such as carbohydrates that can be used as a biomass resource.

\section{References}

Abd-Aziz S (2002) Sago starch and its utilization. J Biosci Bioeng 94(6):526-529

Adawiyah DR, Tomoko S, Kaoru K (2013) Characterization of arenga starch in comparison with sago starch. Carbohydr Polym 92:2306-2313

Ahmad FB, Peter AW, Jean-Louis D et al (1999) Physico-chemical characterization of sago starch. Carbohydr Polym 38:361-370

Alvani K, Xin Q, Richard FT, Colin ES (2011) Physico-chemical properties of potato starches. Food Chem 125:958-965 
Asben A, Tun TI, Khaswar S et al (2011) Study of sago hampas' cellulose conversion to glucose in batch fermentation. In: Proceedings of the 10th international sago symposium, Bogor, Indonesia, pp 83-84

Awg-Adeni DS, Abd-Aziz S, Bujang KB, Hassan MA (2011) Ethanol fermentation from waste starch of sago processing industry by commercial baker's yeast. Proceedings of the 10th international sago symposium, Bogor, pp 78-81

Awg-Adeni DS, Bujang KB, Hassan MA, Abd-Aziz S (2013) Recovery of glucose from residual starch of sago hampas for bioethanol production. Research article. Hindawi publishing corporation. Biomed Res Int 2013:1-8

Cecil JE (1992) Small, medium, and large-scale starch processing. In: Agricultural service bulletin 98, Food and Agriculture Organization, Rome

Flach M (1983) The sago palm. Plant production and protection paper 47. Food and Agriculture Organization, Rome

Flach M (1997) Sago palm. In: Promoting the conservation and use of underutilized and neglected crops, report No.13, Institute of plant genetics and crop plant research, Gatersleben/ International plant genetic resources institute, Rome, p 1-61

Flach M, Schuilling DL (1989) Revival of an ancient starch crop: a review of the agronomy of the sago palm. Agrofor Syst 7:259-281

Fuglie KO (2004) Challenging Bennet's law: the new economics of starchy staples in Asia. Food Policy 29:187-202

Greenhill AR (2006) Food safety and security of sago starch in rural Papua New Guinea. Dissertation, School of Veterinary and Biomedical Science. James Cook University, Townsville, Australia

Hu X, Hongyan L, Benxi W et al (2014) Hydrolysis process of normal rice starch by 1-butanolhydrochloric. Food Hydrocoll 41:27-32

Huijbrechts AML, Desse M, Budtova T et al (2008) Physicochemical properties etherified maize starches. Carbohydr Polym 74:170-184

Ishizaki A (1998) Concluding remarks. In: Jose C, Rasyad A (eds) Proceedings of the 6th international sago symposium. Pekanbaru, Riau

Karim AA, Tie APL, Manan DMA, Zaidul ISM (2008) Starch from the sgo (Metroxylon sagu) palm tree-properties, prospects, and challenges as a new industrial source for food and other uses. Compr Rev Food Sci Food Saf 7(3):215-228

Lai JC, Wan AWAR, Wen YT (2013) Characterisation of sago pith waste and its composites. Ind Crop Prod 45:319-326

Linggang S, Abd-Aziz S, Phang LY, Wasoh H (2011) Sago pith residue as an alternative cheap substrate for bio-butanol production. Proceedings of the 10th international sago symposium, Bogor, pp 75-77

Linggang S, Phang LY, Wasoh MH, Abd-Aziz S (2012) Sago pith residue as an alternative cheap substrate for fermentable sugars production. Appl Biochem Biotechnol 167:122-131

Mishima T (2015) Extraction methods and production processes in starch factories. In: The sago palm. The food and environmental challenges of the 21st century. The Society of the Sago Palm Studies. Kyoto University Press and Trans Pacific Press, pp 242-246

Mishima T, Koutatsu S, Hitoshi N et al (2011) Glucose made from sago residue. Proceedings of the 10th international sago symposium, Bogor, pp 72-74

Mohd AMD, Islam MN, Noor BM (2001) Enzymic extraction of native starch from sago (Metroxylon sagu) waste residue. Starch 53:639-643

Nishimura Y, Takashi M, Hiroshi E (2010) Starch extraction and production. In: The sago palm, the food and environmental challenges of the 21st century. The Society of Sago Palm Studies. Kyoto University Press, Japan, pp 235-242

O'Brien S, Wang Y-J (2008) Susceptibility of annealed starches to hydrolysis by $\alpha$-amylase and glucoamylase. Carbohydr Polym 72(2008):597-607

Peristiwati P, Sayuti JN, Safitri R et al (2011) Bio-ethanol production from sago pith flour hydrolyte by yeasts and Zymomonas mobilis. Proceedings of the 10th international sago symposium, Bogor, Indonesia, p 82 
Santoso B, Koutatsu S, Hitoshi N et al (2015) Effects of micro powder milling on physicochemical properties of sago starch. J Appl Glycosci 62:73-80

Singh N, Nakaura Y, Inouchi N, Nishinari K (2007) Fine structure, thermal and viscoelastic properties of starches separated from Indica rice cultivars. Starch 60:349-357

Singhal RS, Kennedy JF, Gopalakrishnan SM et al (2008) Industrial production, processing, and utilization of sago palm-derived products. Carbohydr Polym 72:1-20

Stahl JA, Lobato LP, Bochi VC et al (2007) Physicochemical properties of pinhão (Araucaria angustifolia, Bert, O. Ktze) starch phosphates. LWT Food Sci Technol 40:1206-1214

United States Census Bureau (2014) International data base. http://www.census.gov/population/ international/data/worldpop/table_population.php. Downloaded on February 10, 2015

Wang WJ, Powell AD, Oates CG (1996) Sago starch as a biomass source: raw sago starch hydrolysis by commercial enzymes. Bioresour Technol 55:55-61

Wang S, Yu J, Yu J (2008) Conformation and location of amorphous and semi-crystalline regions in C-type starch granules revealed by SEM, NMR and XRD. Food Chem 110:39-46

Yamamoto Y (2011) Starch productivity of sago palm and the related factors. Proceedings of the 10th international sago symposium, Bogor, Indonesia, pp 9-15

Open Access This chapter is licensed under the terms of the Creative Commons Attribution 4.0 International License (http://creativecommons.org/licenses/by/4.0/), which permits use, sharing, adaptation, distribution and reproduction in any medium or format, as long as you give appropriate credit to the original author(s) and the source, provide a link to the Creative Commons license and indicate if changes were made.

The images or other third party material in this chapter are included in the chapter's Creative Commons license, unless indicated otherwise in a credit line to the material. If material is not included in the chapter's Creative Commons license and your intended use is not permitted by statutory regulation or exceeds the permitted use, you will need to obtain permission directly from the copyright holder. 